\title{
1. Introduction and synthesis
}

\section{Andrés Solimano}

Economic growth and the process of development do not evolve in a political and institutional vacuum. Economic choices depend on rules, institutions and social constraints that are mediated by a political process. A governance environment characterized by stability, the rule of law, and social cooperation will foster wealth creation provided good economic opportunities are in place. However, in many societies - including the Andean countries - the political process is often messy, institutions are far from being the ideal set of rules that minimize transactions costs and social relations are characterized by conflict and even violence. Ultimately, underdevelopment is not only a problem of lack of economic resources but it is largely associated also with volatile politics, dysfunctional institutions and highly differentiated social structures.

The subject of this book is to understand the main characteristics of political systems, institutions and social structures in the Andean region of Latin America and their impact on and interplay with their economic performance. The Andean region is comprised of Bolivia, Colombia, Ecuador, Peru and Venezuela. ${ }^{1}$ These economies have a per capita income of around US\$2000. They are rich in natural resources such as oil, mining, forestry, biodiversity, fishery, and so on. In the Andean region we find a high frequency of political crises in recent decades. In some countries there is also a high turnover of ministers and other authorities. Constitutions have been reformed in the five Andean countries in the last 15 years. International rankings of quality of institutions as measured by indices of rule of law, effectiveness of regulation, control of corruption and others place the Andean group in a relatively low place of the rankings. Their social structure is characterized by considerable poverty, inequality of income and wealth and social exclusion of certain social groups. In Bolivia, Ecuador and Peru a significant share of the population is of indigenous origin but this is not the case in Colombia and Venezuela. Economic growth has been moderate and volatile in the last two to three decades and some countries, such as Venezuela, have suffered a protracted growth slowdown in the last quarter century. The Andean economies also have had their fair share of economic 
crises associated with terms of trade shocks, changes in capital flows and, at different junctures, internal destabilization.

\subsection{MAIN QUESTIONS}

This book includes comparative cross-country studies along with political economy country papers for each Andean country. The country studies cover at least the 1990s and early 2000s although some of them go even further back and include previous decades as a background to understand current political economy developments in these countries. The volume tries to address the following questions:

a. What are the main characteristics of the political system and the stability of democracy in the Andean countries?

b. What is the frequency of episodes of systemic breakdown (coup d' état, authoritarian regimes, major social upheavals) and collapse of democracy in recent decades in the Andean nations?

c. Are social contracts - as embedded in the constitutions - stable over time? Conversely, what is the frequency of constitutional change in the Andean region?

d. How common are presidential crises and turnover of ministers and other authorities in the Andean countries, reflecting continuous political change and instability in these countries? How can we measure political instability and institutional fragility?

e. What is the interplay between economic and political crises? Is the causality running from political crises to economic crises or from economic crises to political crises? Does one type of crises necessarily lead to the other?

f. What is the quality of institutions in the Andean region as measured by historical indicators and by subjective indices of rule of law, control of corruption, effectiveness of regulations, degree of violence?

g. What are the main political and economic effects of income and wealth inequality in the Andean region? Does inequality worsen governance? Does inequality hamper economic growth?

h. How have the abundance of natural resources and the existence of illegal activities (for example drug traffic) affected the economy and governance conditions in the Andean region?

i. What are the main economic effects of political instability and the quality of institutions on the rate of economic growth and other dimensions of economic development? 


\subsection{MAIN FINDINGS}

The main findings of this book can be summarized as follows:

\section{Political Systems, Constitutions and Crises}

A theme underscored in this book is that formal political systems do not always guarantee strong presidencies and stable democracies. We document a high incidence of presidential crises in the Andean countries. Recent examples are Bolivia in 2003, Ecuador and Peru in 2000, Venezuela in 2001. Traditionally a response to recurrent instability in the Andean countries has been trying to strengthen the presidential system. However, this reform may not, per se, avoid political crises. We are not advocating parliamentary systems either. The point is that strong presidencies may take more than having a presidential system written into the constitution.

In the 1990-2003 period, Colombia, Ecuador, Peru, Bolivia and Venezuela - all five Andean countries - reformed, in major ways, their constitutions as a way to solve their chronic political and economic problems. Historically, say during the 20th century, the frequency of constitutional reform in the Andean region was high. If we interpret (major) constitutional reforms as an attempt to redraw existing social contracts, we find that social contracts are not very stable in the Andean countries. Again we have to distinguish between formal social contracts - as expressed in constitutions - and actual (or 'informal' social contracts), that embed other considerations such as political culture, history and social norms that are certainly more difficult to change than the constitutions. The specific consequences of the last round of constitutional reforms undertaken since the 1990s in the Andean countries merit their own analysis but are beyond the scope of this book. Still the experiences of the last ten or 15 years suggest that changing the constitution is not an overnight fix for the political, economic and social problems of these countries. In addition, new constitutions in some cases may create new problems that probably were not envisaged by the reformers. A sensitive issue, for example, is the expansion of economic rights (and devolution of powers to sub-national levels) sanctioned by some of the new constitutions without concomitant increases in wealth and income to finance the new mandates of the reformed constitutions. This could be relevant for Colombia following the constitution of 1991 and in Venezuela after the constitutional reform of 1999-2000. Other new rules that have proved complex are provisos on the number of political parties, re-election rules, decentralization and others. 


\section{Interplay between Economic and Political Crises}

The Andean countries, some more than others, suffered a number of economic crises in recent decades. From a political economy perspective, the question arises whether these economic crises are always followed by political crises? Of course, we may also have a reverse causality in which political instability leads to economic crises. The answer to the first question is mixed. The Bolivian presidential crisis of 2003 that led to the departure of former President Sánchez de Lozada, who flew to Miami after resigning, came at a time when the incomes of coca growers and poor peasants sharply declined following the policy of coca eradication initiated earlier. So although there were economic and social causes behind the departure of President Sánchez de Lozada, such as the above mentioned squeeze of the incomes of coca growers, it was not a case of a political crisis that follows a macroeconomic crisis (defined as high inflation, continuous currency devaluation, massive decline in GDP, and so on). In contrast, in Ecuador in the last 1990s, the country indeed suffered a severe macroeconomic and financial crisis in 1998-99 characterized by accelerated currency depreciation, inflation, a crisis in the banking system and a decline in gross domestic product of over 9 per cent in 1999. Against this background of economic crisis, President Mahuad was deposed in an indigenous-military uprising in January of 2000. The Ecuadorian political crisis of early 2000 was a clear case in which economic crises preceded a presidential crisis. Of course, these are not purely mechanical relationships and there were also political factors (the management by the President of various conflicts between the sierra and the coast, the relationship with parliament, etc.) behind the collapse of President Mahuad's administration. Anyhow, it is clear that the serious economic crises of 1998-99, intertwined with various political factors, created a climate conducive to a presidential crisis.

Other presidential crises have a different origin. Some of them are related to corruption scandals associated with lack of transparency and weak mechanisms of checks and balances. The departure of Peruvian President Fujimori in 2000, triggered by a bribery scandal involving Chief of Security Vladimiro Montesinos, is a case in point of a corruption-led crisis. In addition, the neo-authoritarian style of government of Fujimori in the 1990s certainly generated increasing levels of social resistance and delegitimization at domestic and international levels that led to such a crisis. Regarding the interplay between economic and political crises, it is apparent that no open, large-scale economic crises happened to occur before or after the departure of Fujimori. In sum, various recent experiences in the Andean region suggest that economic and political crises are not always closely related with each other. Crises in each realm seem to have a certain degree 
of 'autonomy'. One type of crisis (political or economic) is not necessarily preceded or followed by the other.

\section{Stability and Quality of Democracy}

The cross-country analysis and individual country cases in this book show that historically, and recently, democracy has followed cycles (alternating with authoritarianism) in some Andean countries. In the 1960s and 1970s, there were frequent regime changes in which military regimes alternated with democracy in Bolivia, Peru and Ecuador. This underscores the fragility of democracy in these countries. In contrast, in the last four decades democracy has been more stable in Colombia and Venezuela, although these countries have been also affected by chronic internal armed conflict (Colombia) and political polarization (Venezuela).

The Andean countries' experience suggests that the dichotomy between democracy and authoritarianism has to be qualified. This brings us to the complex issue of quality of democracy. At a broad level we may associate the quality of democracy with the efficacy with which political institutions mediate and aggregate the interests, voice and preferences of different individuals, political parties and social groups to produce results that are deemed to be socially desirable (including creating an environment conducive to economic prosperity and stability). Also democracies are incomplete when civic and political rights are not respected and enforced for everyone.

In the context of the Andean countries, the demands by certain social and ethnic groups for an increased voice and political representation are an important test of the quality of democracy. Exclusion and lack of representation of these groups show that democracy is incomplete. Recently we have seen the increasing demands of indigenous groups in Bolivia, Ecuador, and Peru for a greater voice and representation (and eventually autonomy). Traditionally these groups have been largely excluded from the political system although in the 1990s that situation started to be reversed.

Another issue pertaining to the quality and stability of democracy is how democracy manages violence. Colombia is the country with the highest incidence of political violence in the Andean group and in Latin America. The country has suffered for more than four decades an armed conflict that started in the 1960s with socioeconomic and political demands by armed peasants' organizations but that later on became linked to drugtrafficking, changing the original nature of the conflict. Peru also suffered from heightened violence by Sendero Luminoso in the 1980s and early 1990s. Persistent political violence reflects a failure of the democratic system that cannot impose the rule of law and maintain the monopoly of the 
use of force by the institutions of the state. The economic consequences of violence are bound to be severe as it often destroys human lives and valuable economic assets and creates an environment that penalizes the accumulation of capital.

\section{The Nature and Quality of Institutions}

Economic theories of institutions stress that they are created to minimize transaction costs and facilitate economic exchange. However, recent political economy theories take a different approach and envisage institutions as instruments that are designed and maintained to protect the economic and political interests of certain elites which are not necessarily coincident with the interests and general welfare of society. In fact, we may find several historical and recent examples of countries in the world in which dysfunctional institutions can bring stagnation, economic retardation and misery to the population.

The country studies in this volume assess the effectiveness of institutions using both historical and recent indicators of institutional change as well as a set of indices of quality of institutions compiled by the World Bank and the World Economic Forum for a large sample of countries. This allows us to put the institutions of the Andean countries in international comparative perspective. The World Bank-World Economic Forum indices are based on surveys applied to users of these institutions such as individuals, domestic companies and foreign investors. These are subjective indices in the sense of being based on people's opinions of how institutions work. Although there are differences within the Andean group in general these countries rate below some other Latin American countries and the OECD in terms of quality of institutions.

\section{Natural Resources, External Vulnerability and Illegal Activities}

Political institutions interact with economic structures and international conditions in generating certain economic outcomes. Several Andean countries depend on natural resources as their main source of foreign exchange and fiscal revenues. This is the case of oil in Venezuela and Ecuador, of hydrocarbon in Bolivia, copper in Peru, and so on. This dependence on natural resources makes these economies vulnerable to international volatility in commodity prices. Commodity price shocks often create internal cycles of boom and bust in Latin American countries and the Andean group is not an exception in that regard. These cycles occur, in part, because mechanisms of 'financing' the shocks (when they are considered as transitory) are limited given the incomplete nature of 
domestic and international capital markets. Commodity stabilization funds have been set up in several Andean countries with various degrees of success (or failure) in avoiding macroeconomic fluctuations. This dependence on natural resources not only create problems of macroeconomic management (that is, how much to save or spend of a positive shock) but also raise political economy dilemmas, chief among them to decide how and in which sectors to spend revenue windfalls when they occur. Moreover, managing the revenues of natural resources in a transparent way - avoiding rent seeking and corruption - is also a political challenge.

Another issue related to 'natural' resources is the importance of illegal activity such as drug trafficking based in the cultivation of coca leaf and poppies. This has been especially serious in Colombia since the 1960s and 1970s where the revenues of the drug traffic provide resources to rebel groups fueling and perpetuating internal conflict. Also Bolivia and Peru have been affected by drug trafficking problems at least since the 1980s. Also money from illegal activity can have a corrupting effect on institutions debilitating the democratic system and altering economic priorities away from development.

\section{Social Structure, Institutions and Growth}

The social structure of the Andean countries is very complex. It comprises poverty and economic inequality and exclusion of certain social groups. Traditionally, the urban and rural economic elites (landowners, industrialists, bankers, renters) have a disproportionate influence in society. This is in contrast with the limited political and economic influence of low-income groups, including the working class, the unemployed or underemployed, poor peasants and part of the middle class. This social structure generates distributive conflicts over the shares of national income accruing to each group and conflict over access to and use of political power.

A very important role of political institutions is to mediate this latent (or open) social conflict in such ways that society remains reasonably stable and in which the capital accumulation and growth process can develop. When institutions fail to mediate this conflict, for example after a negative shock has occurred, the result is likely to be a combination of both political instability and lower growth. Institutions and governance conditions affect economic growth through factor accumulation and productivity growth. The combination of weak institutions and social conflict creates uncertainty over policies and rules, deteriorates the quality of labor-employer relations and worsens the general business climate in the country. In the external dimension, they can deter international investors and capital inflows also affecting growth. This book examines at country 
level how these mechanisms operate in practice identifying the channels through which social and governance factors affect economic outcomes. The empirical growth literature has ample evidence showing the negative effects of weak governance conditions on economic growth. The country studies included in this volume examine in rich institutional and historical detail the interactions between politics and institutions on the one hand and economic performance and growth on the other.

\section{Geopolitical Considerations}

This book focuses, mainly, on the internal political-economy factors that affect economic performance. Still, we should not neglect the importance of international politics and geopolitical factors. The Andean region is under the direct influence of the United States, its foreign policy and its international financial policies. The influence of Latin American and European governments is also relevant.

The Andean region is affected by the decisions of international financial institutions such as the IMF, the World Bank and the regional development banks. Stabilization plans supported by the Bretton Woods institutions have been critically important at times in affecting the economic and political outcomes in these countries. For example the withholding of a large loan by the IMF to Ecuador in 1999 has been credited with a decisive effect on the eventual demise of President Mahuad in early 2000. Also Plan Colombia actively supported by the United States and some European countries has been instrumental in trying to affect the course of the four-decades-old internal armed conflict in Colombia. The US policy towards drugs in Bolivia and Peru affected the actual patterns of geographical location of drug production in the Andean region and outside it. As already mentioned, policies of coca eradication in Bolivia, encouraged from abroad, altered the fragile social and political balances of the country.

\subsection{ORGANIZATION OF THE BOOK}

This book is organized in two parts besides this introduction. Part I includes two essays, Chapters 2 and 3, that consider the Andean group in international comparative perspective. Chapter 2, 'Governance crises and the Andean region: a political economy analysis' by Andrés Solimano provides a conceptual framework to study governance patterns distinguishing between (a) the political regimes and the constitution, (b) the quality of institutions and (c) the patterns of social conflict and cooperation. The chapter then undertakes an empirical analysis for the Andean region that combines 
historical and recent data on political crises, changes of constitutions for the 20th century along with subjective indices of quality of institutions published by the World Bank and the World Economic Forum. The chapter also illustrates the linkages between governance, inequality and growth performance. Chapter 3, 'Poverty, inequality and governance in the Andean region' by Amanda Glassman and Ashu Handa analyses the main trends in poverty and inequality in the Andean countries. The chapter explores the role of the level and volatility of economic growth, the incidence of recessions and crises, inflation, labor market dynamics and governance factors in terms of their impact on poverty and inequality. The chapter also highlights options for social policy and reform that make compatible growth with social equity and inclusion.

Part II of the book is devoted to five political economy country studies written by well-known economists and political economists of each Andean country. These studies distinguish between institutional and governance factors and economic and social outcomes, exploring the interfaces between both sets of variables. The country studies provide rich institutional detail and place the country experiences in the proper historical and contemporaneous context of each country. Chapter 4, 'The political economy of the crisis in the Andean region: the case of Bolivia' written by George Gray Molina and Gonzalo Chávez make a distinction between a 'governance block' and an 'economic block'. The study covers from 1982 to 2002. The governance block identifies political fragmentation, corruption, ethnic fragmentation and drug trafficking as important governance issues in Bolivia. The economic block documents the stabilization of hyperinflation in the mid1980s and the successive economic and social reforms undertaken in the 1990 s and early 2000s. The authors warn of some critical contradictions of Bolivian society; particularly the fact that the modernizing economic reforms of the 1990s were unable, to a large extent, to tackle a variety of fundamental problems of Bolivia such as its economic dependence on nonrenewable natural resources, the sizeable coca sector that provides the inputs for drug processing, a fragmented political system, a high level of poverty and inequality and a history of exclusion of indigenous groups. These factors have been important in explaining the crises that shook Bolivia in 2003 (and previous crises as well). Chapter 5, 'The economy, conflict and governance in Colombia' by José Antonio Ocampo examines the evolution of governance conditions and economic developments in Colombia in the 1990s and early 2000s. The chapter also provides some discussion of historical trends and data when relevant. The author relates the fourdecades-old internal armed conflict of Colombia started in the 1960s to colonization, the geographical fragmentation of power, intensified by the effects of drug trafficking and its degenerative effects on the rebel groups 
and society at large. In the economic area Ocampo analyses the impact of incomplete adjustment to trade liberalization and the vulnerability of the Colombian economy to external financial cycles. He also notes the tensions between economic openness and an increased role of the state sanctioned by the constitution of 1991 . Ocampo characterizes Colombia as a relatively stable democracy (in terms of duration and continuity since the 1950s) although it coexists with a violent, gang-controlled system largely related to drug trafficking activity and armed conflict.

Chapter 6, 'Political economy of Ecuador: the quandary of governance and economic development' by Gustavo Arteta and Osvaldo Hurtado analyzes the political and economic performance of Ecuador in the 1990s and early 2000s. The authors highlight the fact that Ecuador was the first country in Latin America to begin the transition to democracy in 1977-79 after successive authoritarian regimes. Ecuadorian democracy, however, has been characterized by political instability, a high turnover of presidents and ministers, volatility of laws and reforms, fragmented and conflictive politics, regional divides, influential corporate interests and weak executives. Ecuador grew very rapidly in the 1970s following the oil price boom but the 1980s and 1990s were two decades of low and unstable growth, inflation, recurrent currency devaluations, external vulnerability to commodity price shocks and volatile capital flows. The authors highlight two important political and economic reforms oriented to restoring good governance and economic stability in Ecuador: the constitutional reform of 1998 and the adoption of official dollarization in 2000.

Chapter 7, 'Governance and economic performance in Peru in the 1990s' by Miguel Jaramillo and Jaime Saavedra examines the main politicoinstitutional and economic developments in Peru up to 2000. The authors document that in the late 1980s, before the Fujimori administration, Peru was affected by economic collapse and social turbulence and violence led by the Maoist group Sendero Luminoso. The chapter highlights, however, that the new Fujimori administration combined free market policies with neo-authoritarian political methods. The Fujimori administration's economic program comprised macroeconomic stabilization, liberalization, and privatization. However, Fujimori also showed social concern and an active effort at providing social infrastructure in rural and urban areas was launched. For almost a decade, these policies maintained a certain legitimacy. However, the contradictory mix of social market economics and authoritarian politics in any incomplete democracy proved ultimately explosive when the Montesinos corruption and Mafia-like scandal erupted forcing the departure from the country of President Fujimori who sent his resignation from Japan in mid-2000 where he stayed afterwards in selfimposed exile. 
Chapter 8, 'Venezuela: from stability to turmoil' by Enzo Del Bufalo provides an interpretative essay on the events and factors that led to the government of President Hugo Chávez in the late 1990s and the economic and political polarization of the early to mid-2000s in Venezuela. The author discusses several features of Venezuelan society during the second half of the 20th century and before: the heavy economic reliance on oil (the 'oil rental' model, el modelo rentista), a political system dominated by two traditional political parties (ADECO and COPEI), a varied 'human geography', the influence of the international economy and global politics. This model led to persistent economic decline from the late 1970s, followed by political instability and attempts at either partial reform of the system or to more radicalized alternatives oriented to shattering the prevailing system along neopopulist lines. The author also looks at economic performance in Venezuela and discusses the interplay between governance and economics in the early part of the Chávez administration.

\section{NOTE}

1. The criterion for including the five countries in the definition of 'Andean region' is their membership of CAN (Andean Community of Nations), an economic integration and political agreement that has a governing council, a parliament and forms a customs union. Chile is also an 'Andean country' in a geographical sense but it is not a member of CAN. 
Andrés Solimano - 9781845425715 Downloaded from PubFactory at 04/26/2023 12:55:01PM via free access 